\title{
Limiting pumping from the Edwards Aquifer: An economic investigation of proposals, water markets, and spring flow guarantees
}

\author{
Bruce A. McCarl, ${ }^{1}$ Carl R. Dillon, ${ }^{2}$ Keith O. Keplinger, ${ }^{3}$ and R. Lynn Williams ${ }^{4}$
}

\begin{abstract}
The Edwards Aquifer, near San Antonio, Texas, is an important water source for both pumping and spring flow, which in turn provides water for recreation and habitat for several endangered species. A management authority is charged with aquifer management and is mandated to reduce pumping, facilitate water markets, protect agricultural rights, and protect the species habitat. This paper examines the economic dimensions of authority duties. A combined hydrologic-economic model is used in the investigation. The results indicate that proposed pumping limits are shown to have large consequences for agricultural usage and to decrease the welfare of current aquifer pumping users. However, the spring flow habitat is found to be protected, and the gains from that protection would have to exceed pumping user losses in order for the protection measures to increase regional economic welfare. Agricultural guarantees are shown to cause use value differences, indicating the opportunity for emergence of an active water market. Fixed quantity pumping limits are found to be an expensive way of insuring adequate spring flow.
\end{abstract}

\section{Introduction}

The Edwards Aquifer (EA), near San Antonio, Texas, is an important water source for agricultural, industrial, municipal, ecological, and recreational uses. The San Antonio municipal area almost exclusively relies on EA water, with 1995-1997 annual municipal and industrial usage averaging close to 300,000 acre-feet (af) (370 million $\left.\mathrm{m}^{3}\right)$. Agricultural use, west of San Antonio, averages about 180,000 af (222 million $\mathrm{m}^{3}$ ) [USGS, 1997]. The EA also supports springs at San Marcos and New Braunfels (Comal Springs) which provide habitat for endangered species [Longley, 1992]. In turn, the springflow supports recreation and downstream water usage. Average annual recharge is 637,000 af $\left(786\right.$ million $\left.\mathrm{m}^{3}\right)$, and mid-1990s' average pumping is 480,000 af $\left(592\right.$ million $\left.\mathrm{m}^{3}\right)$. The level of total pumping leaves only 150,000 af $\left(185\right.$ million $\left.\mathrm{m}^{3}\right)$ of water to support spring flow that is much smaller than the historic 50 -year average spring flow (350,000 af, or 432 million $\mathrm{m}^{3}$ ). In recent years, pumping has frequently exceeded recharge [USGS, 1997].

The EA is a fractured limestone formation that recharges quickly. Pumping has grown at about $1.1 \%$ per year during the last 40 years [Collinge et al., 1993]. With increased pumping, the spring flow share of recharge has fallen, and spring flow has twice been close to cessation during the last 5 years. Mean-

\footnotetext{
${ }^{1}$ Department of Agricultural Economics, Texas A\&M University, College Station.

${ }^{2}$ Department of Agricultural Economics, University of Kentucky, Lexington.

${ }^{3}$ Texas Institute for Applied Environmental Research, Tarleton State University, Stephenville, Texas.

${ }^{4}$ California State University, Fresno.

Copyright 1999 by the American Geophysical Union.

Paper number 1998WR900116.

0043-1397/99/1998WR900116\$09.00
}

while, aquifer level fluctuations have increased [Collinge et al., 1993].

There has been considerable concern regarding EA management (see the Water Strategist [1996] or the San Antonio Water System web page, available at http://www.saws.org/ other/htm, for a more detailed history). In the late 1950 s the Edwards Underground Water District was formed to manage the EA. In the late 1980s the western agricultural counties seceded from the district because of disagreements about drought management plans. In the early 1990 s lawsuits were filed asserting that the EA should be declared an underground river and that endangered species in the springs should be protected by maintaining spring flow. The Texas Water Commission declared the EA an underground river subject to surface water law during mid-1992, but this declaration was overturned by the courts during the fall of 1992. In early 1993 the district federal court upheld the endangered species lawsuit and ordered that pumping limits be imposed to protect spring flow. Texas Senate Bill 1477 [Texas Legislature, 1993] (SB1477) (1) establishes the Edwards Aquifer Authority (EAA) to manage the aquifer; (2) requires the EAA to reduce pumping to 450,000 af $\left(560\right.$ million $\left.\mathrm{m}^{3}\right)$ in the near future and to 400,000 af (490 million $\mathrm{m}^{3}$ ) by 2008 ; (3) mandates establishment of water rights; (4) provides for water sales and leases; (5) guarantees that the agricultural share will be a proportional share of historic use and a minimum of 2 af $\left(2468 \mathrm{~m}^{3}\right)$ per acre $(0.405 \mathrm{ha})$; (6) limits off-farm water leasing so that 1 af $\left(1234 \mathrm{~m}^{3}\right)$ per acre must be retained for use in irrigation; and (7) charges the EAA to "protect terrestrial and aquatic life, domestic and municipal water supplies, the operation of existing industries and the economic development of the state."

The EAA formally began operation in fall 1996 and, as of this writing, is expending substantial efforts on water rights establishment. (EAA activities and charter are set out on the EAA home page, available at http:/(www.e-aquifer.com).

This paper provides results from an analysis of issues regarding EAA duties. We report an economic evaluation of the 


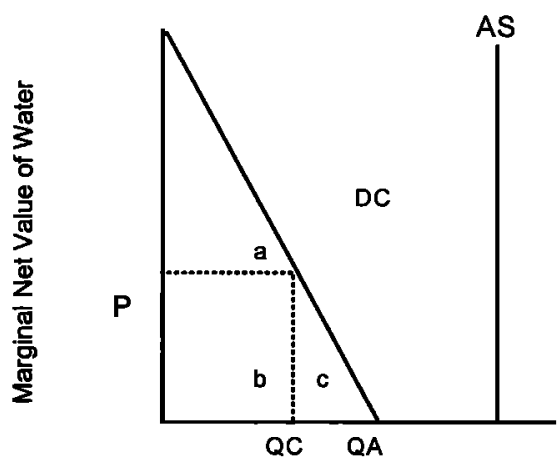

Pumping Usage

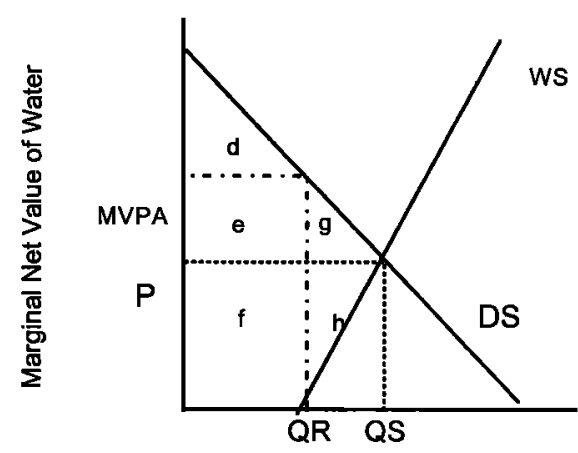

Springflow

Figure 1. Residual versus cooperative use.

450,000 and 400,000 af ( 560 million and 490 million $\mathrm{m}^{3}$ ) pumping limits, agricultural guarantees, and the associated imposition of water markets. Investigations are also performed on the costs of guaranteeing spring flows to protect aquatic life.

The contribution of this paper is best viewed in terms of the total literature. Fundamentally, the paper will build upon prior economic analyses of water allocation and water markets involving multiple users as previously studied in the surface water context by authors such as Vaux and Howitt [1982], Howe et al. [1986], McCarl and Parandvash [1988], Michelsen and Young [1993], and Ward and Lynch [1997] and extend the analysis to simultaneously treat multiple users, uncertainty, and a groundwater case. Second, the model used unifies results from a grid cell-based groundwater hydrology aquifer simulation (using the model described by Thorkildson and McElhaney [1992], which is similar in structure to that of Gharbi and Peralta [1994]) into an economic framework by using a regression summary of the groundwater model results. Third, the case study provides information on the trade-offs and considerations in the interesting EA case which involves, to mention a few salient characteristics, groundwater pumping by three economic sectors, endangered species, rapid recharge, spring flow, groundwater pumping rights, water markets, and agricultural use guarantees (see the web page by G. A. Eckhardt, available at http://www.txdirect.net/users/eckhardt, for a wealth of material on the aquifer). Fourth, this paper is an outgrowth of 10 years of work by the authors on EA issues. Compared to other journal articles involving the team, this is the first to treat nonagricultural and aquifer elevation-spring flow endogenously (Keplinger et al. [1998] and G. D. Schaible et al. (The Edwards Aquifer's water resource conflict: Do USDA farm programs increase irrigation water-use?, draft manuscript, 1998) limit treatment to the agricultural sector). This paper unifies work of the underlying dissertations [Dillon, 1991; Williams, 1996; Keplinger, 1996]. It extends an earlier bulletin on pumping limits [McCarl et al., 1993], analyzing new issues raised by the most recent legislation regarding EA and using an improved analytical framework.

\section{Water Use and Benefits With and Without Pumping Limits}

Before reporting empirical findings, a graphical economic exploration of pumping limits is presented. In particular, we consider three questions: (1) Why have pumping limits?, (2) Should pumping limits be independent of water availability?, and (3) What are the welfare effects of pumping limits?

\subsection{Why Have Pumping Limits?}

A fundamental EA problem regarding efficient water use is the lack of transferrable water rights. (The current lack of property rights inhibits a market solution also rendering EA a common property pool. Provisions in SB1477 [Texas Legislature, 1993] provide a way for pumping interests to acquire and trade rights but do not provide a way for spring flow interests to acquire rights. Rather, a reduction in total use is envisioned leaving the residual for spring flow users.) Currently, individuals can use as much water as they can pump from beneath their land, although actions by EAA will soon limit usage. However, EA is an atypical aquifer. Water recharge is rapid, as is flow. Users jointly determine aquifer elevation, which determines pumping cost. Spring flow users are residual claimants obtaining water left over after pumping usage. The basic economics of such a case are depicted in Figure 1, where (1) the curve DC gives the demand for consumptive use by pumping, after water lifting cost has been paid, by a party that can pump as much as desired; (2) the supply curve AS is the aquifer supply of water; and (3) the demand curve DS is the demand for spring flow (arising through demands for both endangered species existence and instream flows, which in turn affect river ecology, recreation/tourism, and downstream water users).

This graphic format can be used to evaluate the effects of treating spring flow as a residual (as has been the case) versus actively considering spring flow-related demand. In the residual case, since available water (AS) is greater than the maximum pumping demand, pumping users withdraw water until the marginal value product (MVP) of water use is zero (or the MVP at the surface is just equal to water lifting cost). Thus pumping use is QA and the net water value is zero. In turn, unused water ( $A S-Q A=Q R$ ) goes into spring flow, and that market yields a water value of MVPA. Such a situation yields a disparity between the value of water in spring flow and pumping usage arising because of a classic market failure [Baumol and Oates, 1975]. If somehow a market or other institutional mechanism confronted the value of displaced spring flow on pumping user decisions, with WS being the excess supply curve of water after pumping use, then the market would clear 

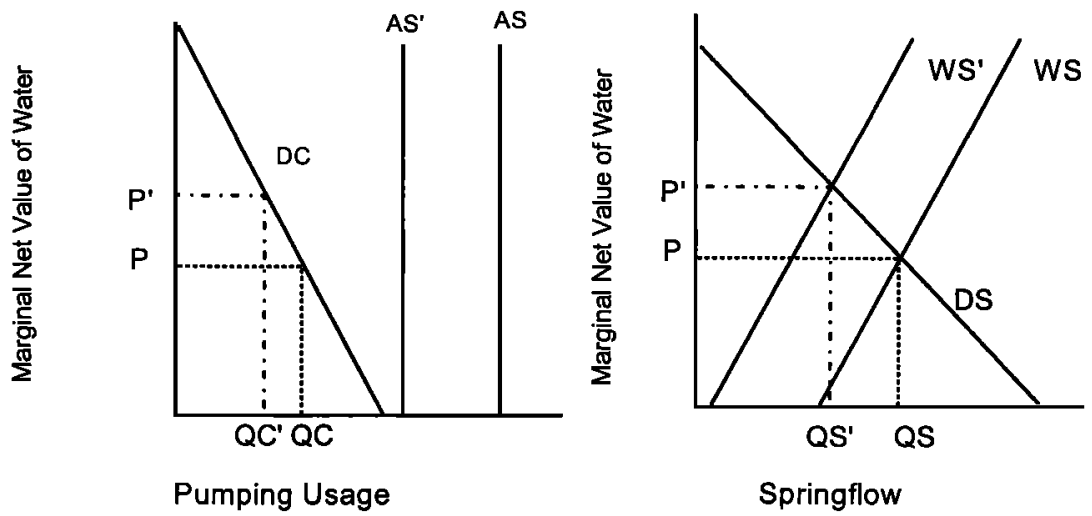

Figure 2. Consideration of supply uncertainty.

at price $\mathrm{P}$ with $\mathrm{QC}$ consumed by pumping and $\mathrm{QS}$ being the amount of spring flow.

This graphical analysis provides the basic rationale for SB1477 pumping limits. Namely, in the absence of a market that reflects spring flow value there is a less than economically efficient amount of water left after pumping use for spring flow. One way of making sure that enough water is left for spring flow is to impose a pumping limit at QC. The parties crafting SB1477 must have felt that an appropriate amount of pumping is somewhere around 400,000 af (490 million $\mathrm{m}^{3}$ ). Such a level of pumping leaves about 100,000 af (120 million $\mathrm{m}^{3}$ ) more for spring flow than is currently the case.

\subsection{Should Pumping Limits Be Independent of Water Availability?}

EA recharge in the last 10 years has varied from 240,000 to 2.4 million af ( 300 million $\mathrm{m}^{3}$ to 3 billion $\mathrm{m}^{3}$ ), while averaging about 630,000 af $\left(780\right.$ million $\left.\mathrm{m}^{3}\right)$ [USGS, 1998]. Figure 2 contains a second water supply/recharge level, $\mathrm{AS}^{\prime}$, which is considerably smaller than the original and leads to a different excess water supply curve ('WS'). Under $\mathrm{AS}^{\prime}$ price $\mathrm{P}^{\prime}$ should be charged and consumptive use should be $\mathrm{QC}^{\prime}$, whereas under "normal" recharge (AS) quantity QC should be pumped. Thus a fixed pumping limit may not be appropriate as recharge varies.

In the empirical work we evaluate the effects of constant 400,000 or 450,000 af ( 490 million or 560 million $\mathrm{m}^{3}$ ) pumping limits and of requiring spring flow to exceed various critical levels. No attempt is made herein (nor do we know of any attempt that has ever been made) to specify a spring flow demand equation and measure economic benefits as they relate to spring flow due to immense data gaps.

\subsection{What Are the Welfare Effects of Pumping Limits?}

To examine this we return to our certainty world of Figure 1. Pumping user welfare without pumping limits is the sum of the areas marked $a, b$, and $c$, while spring flow welfare is $d+e+$ f. However, if the spring flow and pumping markets are in equilibrium, then pumping welfare equals a, while welfare area $\mathrm{b}$ arises because of the pumping limit and accrues to water rights and/or whatever agency is charging water rates while area $\mathrm{c}$ no longer accrues in the pumping sector. (A large portion of the water rights is likely to be assigned to agencies such as the San Antonio Water System, which in turn would need to develop a pricing scheme that would cause an appropriate level of water use. That might lead to such agencies accruing significant amounts of funds, which would need to be redistributed since they are public utilities. In the rest of this paper this component of welfare will be referred to as welfare to water rights and agencies.) Simultaneously, spring flow welfare increases by areas $g+h$. Thus the overall net welfare gain would be $\mathrm{g}+\mathrm{h}-\mathrm{c}$. However, if the analysis is here, $\mathrm{h}=\mathrm{c}$ limited to the pumping sector (as we do below), then there will be a loss of welfare equaling area $c$, which is offset by unmeasured gains in the spring flow sector. We develop estimates of area $c$ that are a lower bound on what the water has to be worth when it is released as spring flow if potential pareto optimality is to be achieved. Thus welfare accruing to pumpers will fall under pumping limits. In Figure 1 pumpers lose areas $\mathrm{b}$ and, $\mathrm{c}$ while $\mathrm{b}$ accrues to the water rights holders and water agencies, which in turn, may redistribute that in various forms to those in the region.

\section{The Modeling Framework}

The empirical counterpart of the Figure 1 analysis was implemented using an equilibrium year economic and hydrologic aquifer simulation model, herein named EDSIM. EDSIM is the unification of cumulative developments by Dillon [1991], Williams - [1996], McCarl et al. [1993], Lacewell and McCarl [1995]; Keplinger [1996], and Keplinger et al. [1995], with this being the first comprehensive publication. EDSIM depicts pumping use by the agricultural, industrial, and municipal sectors while simultaneously calculating pumping lift, ending elevation, and spring flow. EDSIM simulates choice of regional water use, irrigated versus dryland production, and irrigation delivery system (sprinkler or furrow) such that overall regional economic value is maximized. Regional value is derived from a combination of perfectly elastic demand for agricultural products, agricultural production costs, price elastic municipal demand, price elastic industrial demand, and lift sensitive pumping costs. The municipal demand elasticity is drawn from Griffin and Chang [1991], while the industrial elasticity is from Renzetti [1988]. The quantity demanded by municipal users depends upon rainfall and climatic conditions following Griffin and Chang [1991]. Agricultural water use dependency on climate is developed using EPIC [Williams et al., 1989].

An algebraic representation of the fundamental relationships in EDSIM is presented below. A complete model specification is available in the source GAMS code. All variables are typed in upper case, while all the parameters are typed in lower case. 
The unifying force in EDSIM is the objective function. EDSIM is a two-stage stochastic program with recourse model [Dantzig, 1955]. The model is solved as one simultaneous model but includes variables at two "stages" of uncertainty. The first (stage 1) set of variables depicts decisions on irrigation investment and crop mix and are constant across all states of nature chosen on the basis of average irrigation returns before anything is known about the weather event. The second (stage 2) set of variables are chosen with knowledge of state of nature (irrigation scheduling, crop sale, and nonagricultural water use). Thus, following Dantzig, the objective function involves two types of terms, one where certain costs are borne regardless of the uncertain outcome and the other where stochastically based decisions are weighted by their probability.

The first stage which is constant across all stochastic outcomes appears in the first three lines of the objective function, equation (1), and contains (1) the differential costs of irrigation development (costirr) by lift zone type ( $\mathrm{z}$ ) times acres developed (IRRLAND) in a place (p) for lift zone $z$ and (2) the cost of establishing the crop mix times the acres in the mix (IRRMIX, DRYMIX) by place and irrigated or dryland crop (irracrecost, dryacrecost).

The second stage is defined for each state of nature (r) depicting alternative weather, recharge, and irrigation demand conditions and is weighted by probability (prob) as derived from historical observations. The second stage objective terms include the following state of nature dependent components: (1) irrigation and dryland net income (irrincome, dryincome) by place, lift zone, crop (c) and irrigation strategy (s) times acres produced (IRRPROD, DRYPROD); agricultural pumping cost involving per unit cost (AGPUMPCOST) times volume pumped (AGWATER) by month (m); integrals under the municipal and industrial demand curves (the terms with MUN, IND) by place; and municipal and industrial pumping costs defined in an analogous manner to the above agricultural pump cost term (MIPCOST).

\section{1. Óbjective Function}

Algebraically, the objective function is as follows:

$$
\begin{aligned}
& \text { maximize }-\sum_{\mathrm{p}} \sum_{\mathrm{z}} \operatorname{costirr}_{\mathrm{z}} \text { IRRLAND }_{\mathrm{pz}} \\
& -\sum_{\mathrm{p}} \sum_{\mathrm{k}} \sum_{\mathrm{z}} \text { irracrecost }_{\mathrm{pk}} \text { IRRMIX }_{\mathrm{pzk}} \\
& -\sum_{\mathrm{p}} \sum_{\mathrm{k}} \sum_{\mathrm{z}} \text { dryacrecost }_{\mathrm{pk}} \text { DRYMIX }_{\mathrm{pzk}} \\
& +\sum_{\mathrm{r}} \operatorname{prob}_{\mathrm{r}}\left(\sum_{\mathrm{p}} \sum_{\mathrm{z}} \sum_{\mathrm{c}} \sum_{\mathrm{s}} \text { irrincome }_{\mathrm{rcs}} \text { IRRPROD }_{\mathrm{pzrcs}}\right. \\
& +\sum_{\mathrm{p}} \sum_{\mathrm{c}} \text { dryincome }_{\mathrm{rc}} \text { DRYPROD }_{\mathrm{prc}} \\
& -\sum_{\mathrm{p}} \sum_{\mathrm{z}} \sum_{\mathrm{m}} \mathrm{AGPCOST}_{\mathrm{pzr}} \text { AGWATER }_{\mathrm{pztm}} \\
& +\sum_{\mathrm{p}} \sum_{\mathrm{m}} \int \operatorname{mprc}_{\mathrm{prm}}\left(\mathrm{MUN}_{\mathrm{prm}}\right) \mathrm{dMUN}_{\mathrm{prm}} \\
& +\sum_{\mathrm{p}} \sum_{\mathrm{m}} \int \mathrm{iprc}_{\mathrm{prm}}\left(\mathrm{IND}_{\mathrm{prm}}\right) \mathrm{dIND}_{\mathrm{prm}}
\end{aligned}
$$

$$
\left.-\sum_{\mathrm{p}} \sum_{\mathrm{z}} \operatorname{MIPCOST}_{\mathrm{pr}}\left(\mathrm{MUN}_{\mathrm{pr}}+\operatorname{IND}_{\mathrm{pr}}\right)\right)
$$

where dMUN and dIND indicate the variables being integrated over.

The above objective function is maximized subject to the constraints in equations (2)-(17), which link the stage 1 and stage 2 variables and constrain the stage 2 variables to be conditioned by the stage 1 variables (e.g., allowing only as much irrigation as the amount of installed irrigation equipment and requiring the irrigation schedule to be consistent with the irrigated crop mix).

\subsection{Irrigation Water Use Accounting}

Irrigation water use is added up into the variable AGWATER by taking the water use per acre by each strategy times the acres produced (IRRPROD) by place (p), lift zone (z), state of nature (r), and irrigation strategy (s).

$$
\sum_{c} \sum_{s} \text { wateruse }_{\text {prcsm }} \text { IRRPROD }_{\text {pzrcs }}-\text { AGWATER }_{\text {pzrm }} \leq 0
$$$$
\text { for all } \mathrm{p}, \mathrm{z}, \mathrm{r}, \mathrm{m}
$$

The AGWATER variable is used in the hydrologically based accounting of aquifer elevation, pump lift, and spring flow.

\subsection{Total Farm Land Availability}

Total acreage irrigated (IRRLAND) plus that converted to dryland use (MAKEDRY) cannot exceed the total land historically irrigated by place $\mathrm{p}$ and lift zone $\mathrm{z}$.

$$
\begin{array}{r}
+ \text { MAKEDRY }_{\mathrm{pz}}+\text { IRRLAND }_{\mathrm{pz}} \leq \text { landavail }_{\mathrm{pz}} \\
\text { for all } \mathrm{p}, \mathrm{z}
\end{array}
$$

\subsection{Irrigated Land Availability}

Total acreage irrigated (IRRLAND) in a place and lift zone is set equal to irrigated production by crop and irrigation strategy (IRRPROD) in that place and lift zone. The land to be irrigated is the same across all states of nature (note that IRRLAND does not have an $r$ subscript), but the land can be assigned to different irrigation strategies depending on state of nature. Irrigated crop choice is constrained by (6) and (7).

$$
\sum_{c} \sum_{s} \text { IRRPROD }_{\text {pzrcs }}-\text { IRRLAND }_{\mathrm{pz}} \leq 0
$$

$$
\text { for all } r, p, z
$$

\subsection{Dryland Availability}

Acres in each place converted to dryland (MAKEDRY) summed across lift zones are set equal to dry production by crop (DRYPROD). The acreage converted is a stage 1 variable and is therefore equal across all states of nature. Initially, dryland production is zero since we are modeling only the irrigated portion of the region. This equation, however, allows conversion to dryland if the cost of water makes the conversion profitable.

$$
\sum_{c} \text { DRYPROD }_{\mathrm{prc}}-\sum_{z} \text { MAKEDRY }_{\mathrm{pz}} \leq 0
$$


The acres converted to dryland are summed across the lift zones (since no pumping is done and thus lift zone is not an a cost factor for dryland production) and are set equal to total dryland cropping across all crops (c) for a place (p) and state of nature (r). The choice of dryland crop mix is (8) and (9).

\subsection{Irrigated Crop Mix Restriction}

These constraints require that the irrigated crop production for a place and lift zone be a convex combination of prespecified allowable crop mixes (where IRRMIX gives the weight in the combination and selects from $\mathrm{k}$ multicrop mix possibilities) following $\mathrm{McCarl}$ [1982]. The crop mix variables are stage 1 activities and do not differ by state of nature. The constraints require that the crops in each stage 2 state of nature summed over irrigation schedule(s) equal the stage 1 crop mix chosen. Thus the model can adjust the water use strategy to the climate, but the crop mix is chosen before exact weather conditions are known. The mixes chosen can differ by place and lift zone. Constraint (6) insures that the acres chosen by crop across all irrigation strategies $s$ for a state of nature $r$ are a weighted average of the relative frequency of that crop in that region and lift zone where IRRMIX is the weights in the average. Equation (7) forces the acres in the average to equal the acres farmed.

$$
\begin{array}{r}
\sum_{\mathrm{s}} \text { IRRPROD }_{\mathrm{pzrcs}}-\sum_{\mathrm{k}} \text { imix }_{\mathrm{pck}} \text { IRRMIX }_{\mathrm{pzk}} \leq \mathbf{0} \\
\sum_{\mathrm{c}} \sum_{\mathrm{s}} \text { for all } \mathrm{p}, \mathrm{z}, \mathrm{r}, \mathrm{c}_{\mathrm{c}} \text { IRPROD }_{\mathrm{pzrcs}}-\sum_{\mathrm{k}} \sum_{\mathrm{p}} \text { imix }_{\mathrm{pck}} \text { IRRMIX }_{\mathrm{pzk}}=0 \\
\text { for all } \mathrm{p}, \mathrm{z}, \mathrm{r}
\end{array}
$$

The mix data include historical and survey-based mixes. The survey-based mixes arose from a farm survey [Schiable, 1996] that asked irrigators what crop mix changes they would employ if the farm program were eliminated. These constraints cause the solution to cause realistic crop mixes without requiring modeling of detailed farm level resource allocation as argued by $M c$ Carl [1982].

\subsection{Dryland Crop Mix Restriction}

This is the dryland counterpart of (6) and (7) and requires that dryland production falls into a convex combination of previously observed dryland crop mixes by place. The DRYMIX variables are the weights in the convex combinations and multiply observed mixes. Constraint (9) requires that the total dryland acres in the mix equal the total dryland acres farmed. The dryland crop mixes are developed from historical dryland acreage statistics for the region.

$$
\text { DRYPROD }_{\mathrm{pzrc}}-\sum_{\mathbf{k}} \mathrm{dmix}_{\mathrm{pck}} \text { DRYMIX }_{\mathrm{pzrk}} \leq 0
$$

$$
\text { for all } \mathrm{p}, \mathrm{z}, \mathrm{r}, \mathrm{c}
$$

$$
\sum_{c} \text { DRYPROD }_{\mathrm{prc}}-\sum_{\mathrm{c}} \sum_{\mathrm{k}} \mathrm{dmix}_{\mathrm{pck}} \text { DRYMIX }_{\mathrm{pk}}=\mathbf{0}
$$

\section{for all $\mathrm{p}, \mathrm{r}$}

\subsection{Agricultural Pumping Cost Determination}

Per-acre-foot agricultural pumping cost (AGPCOST) is set equal to a regression estimated linear function of lift
(AGLIFT) by place, lift zone, and state of nature where agcosti is the intercept and agcostl is the slope.

$$
-\mathrm{AGPCOST}_{\mathrm{pzr}}+\operatorname{agcosti}+\operatorname{agcostl} \mathrm{AGLIFT}_{\mathrm{pzr}}=0
$$

for all $\mathrm{p}, \mathrm{z}, \mathbf{r}$

\subsection{Regional Base Pump Lift Equation}

Base regional pumping lift is determined based on ending elevation. The base aquifer lift (LIFT) in a region is set equal to the difference between ending elevation (ENDWATER) and a zero lift level for each state of nature (r) and region (w).

- LIFT $_{w r}+$ ENDWATER $_{w r}=$ zero lift $_{w}$ for all w, $r$

\subsection{Agricultural Lift Determination}

The agricultural lift in a place and lift zone is set equal to the overall regional lift plus the agricultural lift difference (agdiff) for each state and lift zone.

$$
\begin{aligned}
-\operatorname{AGLIFT}_{\mathrm{pzr}}+\mathrm{LIFT}_{\mathrm{wT}} & =-\operatorname{agdiff}_{\mathrm{pz}} \\
& \text { for all } \mathrm{r}, \mathrm{z}, \mathrm{w}, \mathrm{p} \in \operatorname{reg}(\mathrm{w})
\end{aligned}
$$

The agdiff was calculated as a weighted average of the agricultural pumplift differential from the eastern area average lift in the GWSIMIV input data [Thorkildsen and McElhaney, 1992] for lands falling in the three lift zones.

\subsection{Nonagricultural Pumping Cost Calculation}

The per-acre-foot municipal and industrial pumping cost (MIPCOST) is set equal to a regression estimated linear function of the calculated $M$ and I lift (MILIFT) by place and state of nature where micosti is the intercept and micostl is the slope.

$$
-\operatorname{MIPCOST}_{\mathrm{pr}}+\text { micosti }+ \text { micostl } \operatorname{MILIFT}_{\mathrm{pr}}=0
$$

for all $\mathrm{p}, \mathrm{r}$

\subsection{Nonagricultural Lift Determination}

The municipal and industrial lift in place $\mathrm{p}$ falling in region $\mathrm{w}$ is set equal to the overall regional lift level for state $\mathbf{r}$ plus the place dependent municipal and industrial lift difference.

$$
\begin{aligned}
- \text { MILIFT }_{\mathrm{pr}}+\operatorname{LIFT}_{\mathrm{wr}} & =-\operatorname{midiff}_{\mathrm{p}} \\
& \text { for all } \mathrm{r}, \mathrm{w}, \mathrm{p} \in \operatorname{reg}(\mathrm{w})
\end{aligned}
$$

The midiff was calculated as a weighted average of the nonagricultural pumplift differential from the eastern area average lift in the GWSIMIV input data [Thorkildsen and McElhaney, 1992] for pumping falling in a county.

\subsection{Regional Ending Elevation Determination}

The ending aquifer elevation by region (ENDWAT) is computed through a linear equation that includes an intercept term (rendi), a recharge parameter (rendr) times the state dependent exogenous level of recharge(rech), an initial water level parameter (rende) times the endogenous initial water level (INITWAT) term, and a water-use-by-region parameter (rendu) times summed municipal, industrial, and agricultural use. Initial water level in both this and the adjacent eastern or western region affects this region's ending water level. Thus the subscript $\mathrm{w} 2$ is used to sum across both regions. The same is true for usage. The rend terms in the equation are regression response surface estimates over the entire set of results from a 
wide variety of aquifer hydrology model runs as described in section 5 .

$$
\begin{aligned}
& \text { ENDWAT }_{\mathrm{wr}}=\text { rendi }_{\mathrm{w}}+\sum_{\mathrm{m}} \text { rendr }_{\mathrm{w}} \text { rech }_{\mathrm{rm}} \\
& +\sum_{\mathrm{w}_{2}} \text { rende }_{\mathrm{ww}_{2}} \text { INITWAT }_{\mathrm{w}_{2}}+\sum_{\mathrm{w}_{2}} \text { rendu }_{\mathrm{ww} 2} \\
& +\sum_{\mathrm{p} \in \mathrm{reg}\left(\mathrm{w}_{2}\right)} \sum_{\mathrm{m}}\left(\mathrm{MUN}_{\mathrm{prm}}+\mathrm{IND}_{\mathrm{prm}}\right. \\
& \left.+\sum_{z} \text { AGWATER }_{\mathrm{przm}}\right) \quad \text { for all } \mathrm{w}, \mathrm{r}
\end{aligned}
$$

\subsection{Initial Elevation Balance}

Initial elevation is set equal to the probability weighted average of ending elevation by region.

$$
- \text { INITWAT }_{w}+\sum_{r} \text { prob }_{r} \text { ENDWATER }_{w r}=0
$$

for all $w$

\subsection{Spring Flow Equation}

Flow for the two springs is predicted from a regressionbased forecast of similar structure to that used in the ending water level equation (15). The regression-based forecast considers only the cumulative use and recharge summed over months $\mathrm{m}^{*}$ which proceed a particular month (m). Thus the regression equation for August will consider the initial water level and all pumping use in recharge from January through August. A linear equation is used that includes an intercept term (rsprni), a recharge parameter (rsprnr) times the state dependent exogenous level of recharge (rech), an initial water level parameter (rsprne) times the endogenous initial water level (INITWAT) term, and a water-use-by-region parameter (rsprnu) times summed municipal, industrial, and agricultural use. This equation is defined for each spring during each month for each state of nature. Equation estimation and resultant parameters is described in section 5 .

$$
\begin{aligned}
& \text { SPRNFLO }_{\mathrm{srm}}=\text { rsprni }_{\mathrm{sm}}+\sum_{\mathrm{m}^{*} \leq \mathrm{m}} \text { rsprnr }_{\mathrm{smm}^{*}} \text { rech }_{\mathrm{rm}^{*}} \\
& +\sum_{\mathrm{w}} \text { rsprne }_{\mathrm{smw}} \text { INITWAT }_{\mathrm{w}}+\sum_{\mathrm{w}} \sum_{\mathrm{p} \in \mathrm{reg}(\mathrm{w})} \sum_{\mathrm{m}^{*} \leq \mathrm{m}} \mathrm{rsprnu}_{\mathrm{smwm}} \\
& \cdot\left(\mathrm{MUN}_{\mathrm{prm}^{*}}+\mathrm{IND}_{\mathrm{prm}^{*}}+\sum_{\mathrm{z}} \operatorname{AGWATER}_{\mathrm{przm}^{*}}\right)
\end{aligned}
$$

for all s, r, m

\section{Model Component Elaboration}

There are several key characteristics of the EDSIM framework which merit discussion. First, EDSIM is a price endogenous optimization model following the work of $\mathrm{McCarl}$ and Spreen [1980]. Water is allocated to the highest and best use in terms of generating greatest net economic value. Thus EDSIM is not constrained to simulate current use, but rather it simulates best use in an economic sense. However, when it ran without pumping limits under current water demand, the EDSIM water use solution corresponds closely to water use in the current unrestricted pumping environment where the marginal water value is basically driven to zero, as in Figure 1. When EDSIM is executed with the pumping or spring flow limits imposed, the results simulate the "best" total regional economic outcome under that limitation as well as permitting comparison with the existing situation.

Second, EDSIM incorporates uncertainty. The uncertain phenomena involves recharge and associated climate. The handling of uncertainty in EDSIM is based upon discrete stochastic programming or stochastic programming with recourse [Dantzig, 1955; McCarl and Parandvash, 1988; Ziari et al., 1995]. Decision making is modeled as a two-stage process. In stage 1 , decisions on irrigated acreage, furrow versus sprinkler irrigation, and crop mix are made which are state of nature independent. In stage 2, water use decisions are made which depend upon the state of nature. EDSIM maximizes average regional welfare over the recharge events and their probabilities. (The recharge distribution used herein is a nine-event representation of the recharge and climate distribution observed from 1934 to 1992 . Dillon [1991] discusses its initial development and statistical characteristics.) This uncertainty model depicts an important fact coloring the agricultural production environment. Namely, the amount of agricultural irrigated acreage, the choice of furrow verus sprinkler, and the crop mix are generally chosen before the weather is revealed and persist as fixed decisions once the weather is known. However, the use of water is dependent on recharge and climate after their characteristics become known. Thus municipal demand, industrial demand, and choice of irrigation strategy depend upon water available.

Third, EDSIM incorporates hydrological processes based upon a regression summary of the Texas Water Development Board's EA simulation model [Thorkildson and McElhaney, 1992]. The estimated regression equations are directly incorporated as EDSIM equations in (15) and (17). Regression equations were estimated for monthly spring flow and ending elevation at two wells (one in Uvalde county and one in San Antonio) during the year at hand.

Fourth, EDSIM depicts economic competitive equilibrium water use by municipal, industrial, and agricultural interests. The agricultural submodel assumes farmers are profit maximizers choosing between dryland and irrigated cropping under 1996 commodity prices. The irrigation strategy depends on the recharge/weather situation, pumping lift, crop mix, and installed irrigation system. Three pumping lift zones and two irrigation delivery systems (furrow and sprinkler) are considered. The municipal and industrial submodels derive an economic equilibrium by intersecting explicit demand curves for water with their water supply prices. The supply price equals the pumping cost plus any water opportunity cost stimulated by pumping or spring flow restrictions. Thus EDSIM allocates water among sectors so that to the extent allowed by the scenario, marginal productivity is equalized and the overall level of economic activity is maximized.

Fifth, EDSIM is run under year-2000 demand projections. The year-2000 conditions assume that municipal and industrial demands expand according to growth-based, regional forecasts by the Texas Water Development Board.

Sixth, the EDSIM data evolved over time from efforts by Dillon [1991], McCarl et al. [1993], Williams [1996], Lacewell and McCarl [1995], and Keplinger [1996]. The agricultural part was largely specified using EPIC and extension service regional budgets [Lacewell and McCarl, 1995; Keplinger, 1996]. 
Table 1. Regression Coefficients for Annual Comal and San Marcos Spring Flow

\begin{tabular}{lccccc}
\hline & \multicolumn{3}{c}{ Dependent Variable } \\
\cline { 2 - 5 } \multicolumn{1}{c}{ Parameter } & \multicolumn{2}{c}{ Spring Flow, Acre-Feet } & & \multicolumn{2}{c}{ Elevation, Feet Above Sea Level } \\
\cline { 2 - 3 } \cline { 5 - 6 } & Comal & San Marcos & & J17 Ending & Sabinal Ending \\
\hline J17 starting elevation, feet above sea level & 2,651 & 412 & 0.542 & 0.348 \\
Sabinal starting elevation, feet above sea level & 551 & 0.0 & 0.155 & 0.583 \\
Annual recharge, acre-feet & 0.080 & 0.024 & & 0.000019 \\
Western pumping, acre-feet & -0.04 & -0.0005 & & -0.000028 & -0.000091 \\
Eastern pumping, acre-feet & -0.28 & -0.025 & -0.000136 & -0.000059 \\
Intercept & -1924677 & -203976 & 225.41 & 102.22 \\
$R^{2}$ & 0.93 & 0.77 & 0.95 & 0.96 \\
\hline
\end{tabular}

One acre-foot equals $1234 \mathrm{~m}^{3} ; 1$ foot equals $0.3048 \mathrm{~m}$.

Seventh, EDSIM is a single-equilibrium-year model. It starts from a single initial elevation across all recharge states. This initial elevation is set equal to the probabilistic weighted average of the ending elevations via (16). This means that the model always returns to an average initial elevation and does not account for decision making that would occur in a period of multiyear drought.

\section{Hydrologic Regressions}

The hydrologic regressions have large influences on the results and thus merit discussion. Equations were estimated that predict monthly spring flow at two springs and ending elevation at two wells. The monthly spring flow equations predict flow in month $m$ during this year as a simple linear function of beginning year (January) well elevations, water pumping between January and month $\mathrm{m}$, and recharge in months up to month $\mathrm{m}$ following a linear functional form. The same functional form was used for the ending elevations, but only a end of December equation was estimated. The response function equations were estimated from the results of 136,800 monthly observations from the single layer, porous medium, aquifer simulation model documented by Thorkildson and McElhaney [1992]. These observations arose from model runs under all combinations of 57 recharge states, 25 pumping alternatives, and 8 initial water levels observing 12 monthly results for each case. Annual versions of all equations are given in Table 1 . Note that because the simulation model was the data source, we do not have a true underlying random distribution. Thus $t$ statistic significance levels are not presented as they cannot be interpreted as valid statistical tests. We do however provide $R^{2}$ as a measure of fit.

The equations fit the simulated data well and contain expected results in terms of pumping, elevation, and recharge effects on the spring flow and ending elevation. Two features of the regression results merit discussion. First, western pumping and elevation have much smaller effects than their eastern counterparts. This is due to a granite intrusion (called the Knippa Gap) that separates the east and west EA regions, restricting flows and hydraulic pressure transmission. This finding manifests itself in later results. (These results have large implications for regional water use when spring flow is to be protected. Thus, we decided to try to verify the results using historical (rather that simulated) data. Annual regressions over historical data yielded essentially the same east/west results although multicollinearity did not permit estimation of the exact same equation. (See work by Keplinger and McCarl [1995] for details)). Second, the spring flow regression results do not fit the flows at San Marcos Springs as well as at Comal Springs but Comal is the critical spring. (Also as a reviewer pointed out, the GWBSIM model has more difficulty in predicting San Marcos spring flows.)

\section{Base Model Results}

The base model results appear in Table 2. Agricultural water use averages about 170,000 af $\left(210\right.$ million $\left.\mathrm{m}^{3}\right)$ with nonagricultural water use averaging around 330,000 af (410 million $\left.\mathrm{m}^{3}\right)$. Maximum agricultural water use is about 190,000 af $(230$ million $\mathrm{m}^{3}$ ), and nonagricultural water use is about 350,000 af $\left(430\right.$ million $\left.\mathrm{m}^{3}\right)$, for a total of 540,000 af $\left(670\right.$ million $\left.\mathrm{m}^{3}\right)$. This corresponds closely to historic maximum water use [USGS, 1997]. The smallest monthly spring flow at Comal, the most sensitive spring, is zero, an expected result given that a very dry year is in the data set. In terms of welfare, agricultural net income averages $\$ 6.4$ million with a municipal consumers' surplus of about $\$ 471$ million (being so large since it comes from a constant elasticity demand curve which goes asymptotic to the axis) and industrial surplus about $\$ 2.8$ million. Rents to water rights/agencies (area b from above) are around $\$ 7$ million. Total average welfare, the model maximand, is $\$ 487$ million across all sectors. All available acreage is irrigated (only acres irrigated in 1992 are included as land available in the model). Agricultural income has a $44.55 \%$ coefficient of variation. The optimal beginning (January) elevation for the J17 reference well in San Antonio is 642 feet (196 m). However, under dry conditions the ending elevation is as low as 626 feet (191 m).

\section{Model-Based Policy Analysis}

We are now in a position to investigate issues regarding EAA duties. We begin by examining the implications of the two SB1477 pumping limits, then follow that with an investigation of the pumping levels needed to maintain selected spring flow levels. Last, we turn attention to the implications of agricultural guarantees and associated water marketing.

\subsection{SB1477 Pumping Limits}

As stated above, SB1477 imposes pumping limits of 450,000 af $\left(560\right.$ million $\left.\mathrm{m}^{3}\right)$ in the near future and 400,000 af (490 million $\mathrm{m}^{3}$ ) in the longer term. We simulate this by bounding the sum of the IND, MUN, and AGWATER variables to not exceed the pumping limit. The second and third columns of 
Table 2. Comparison of Welfare Effects of Alternative Water Management Plans

\begin{tabular}{|c|c|c|c|c|c|c|c|}
\hline & \multirow[b]{3}{*}{ Base } & \multicolumn{6}{|c|}{ Change From Base Scenario } \\
\hline & & \multicolumn{2}{|c|}{ Pumping Limits, Acre-Feet } & \multicolumn{4}{|c|}{ Spring Flow Limits, Cubic Feet per Second } \\
\hline & & 450,000 & 400,000 & 50 & 100 & 150 & 200 \\
\hline \multicolumn{8}{|c|}{ Average Welfare Measures } \\
\hline Agriculture income, $10^{6} \$$ & 6.36 & -0.40 & -1.19 & -0.08 & -0.24 & -0.27 & -0.49 \\
\hline Percent change & .. & -6.33 & -18.69 & -1.20 & -3.82 & -4.28 & -7.73 \\
\hline Municipal surplus, $10^{6} \$$ & 471.20 & -1.90 & -4.36 & -0.26 & -0.43 & -1.90 & -3.16 \\
\hline Percent change & ... & -0.40 & -0.93 & -0.06 & -0.09 & -0.40 & -0.67 \\
\hline Industry surplus, $10^{6} \$$ & 2.77 & -0.06 & -0.13 & 0.00 & 0.00 & -0.05 & -0.08 \\
\hline Percent change & $\cdots$ & -1.99 & -4.61 & -0.22 & -0.36 & -1.67 & -2.78 \\
\hline Authority surplus, $10^{6} \$$ & 6.99 & 2.06 & 4.55 & 0.32 & 0.61 & 2.03 & 3.26 \\
\hline Percent change & $\cdots$ & 29.48 & 65.10 & 4.63 & 8.74 & 29.08 & 46.70 \\
\hline Total surplus, $10^{6} \$$ & 487.32 & -0.30 & -1.13 & -0.02 & -0.07 & -0.19 & -0.47 \\
\hline Percent change & $\cdots$ & -0.06 & -0.23 & -0.005 & -0.01 & -0.04 & -0.10 \\
\hline \multicolumn{8}{|c|}{ Agricultural Activity Measures } \\
\hline Irrigated land, $10^{3}$ acre-feet & 79.89 & -13.89 & -26.98 & -4.16 & -11.19 & -13.89 & -18.64 \\
\hline Dryland usage, $10^{3}$ acre-feet & 0 & 13.89 & 26.98 & 4.16 & 11.19 & 13.89 & 18.64 \\
\hline Agricultural income coefficient of variation, \% & 44.56 & -1.84 & -0.93 & -1.41 & -3.74 & -4.36 & -4.57 \\
\hline \multicolumn{8}{|c|}{ Water Use Measures } \\
\hline East agricultural, $10^{3}$ acre-feet & 81.85 & -32.85 & -63.41 & -9.35 & -24.81 & -32.55 & -44.23 \\
\hline West agricultural, $10^{3}$ acre-feet & 87.41 & -8.82 & -14.08 & 0.03 & 0.79 & 0.37 & -1.33 \\
\hline East nonagricultural, $10^{3}$ acre-feet & 322.00 & -9.92 & -22.49 & -1.47 & -2.42 & -10.50 & -16.89 \\
\hline West nonagricultural, $10^{3}$ acre-feet & 9.73 & -0.48 & -1.01 & -0.01 & -0.01 & -0.12 & -0.20 \\
\hline Total use, $10^{3}$ acre-feet & 500.99 & -52.08 & -100.99 & -10.80 & -26.44 & -42.80 & -62.65 \\
\hline \multicolumn{8}{|c|}{ Hydrologic Result } \\
\hline Comal spring flow, $10^{3}$ acre-feet & 97.56 & 93.12 & 183.91 & 21.83 & 54.49 & 86.17 & 123.55 \\
\hline San Marcos spring flow, $10^{3}$ acre-feet & 64.16 & 9.88 & 19.56 & 2.34 & 5.85 & 9.25 & 13.25 \\
\hline J17 Well End Elevation, feet & 641.83 & 22.25 & 44.01 & 5.18 & 12.90 & 20.58 & 29.57 \\
\hline Minimum Comal Spring flow, cfs & 0 & 139.72 & 250.56 & 50.00 & 100.00 & 150.00 & 200.00 \\
\hline
\end{tabular}

One acre-foot equals $1234 \mathrm{~m}^{3} ; 1$ cubic foot equals $0.028 \mathrm{~m}^{3} ; 1$ foot equals $0.3048 \mathrm{~m}$.

Table 2 give results from EDSIM under those pumping limits. The total loss in regional welfare (equivalent to area $\mathrm{c}$ in Figure 1) is $\$ 300,000$ per year under the 450,000 af limit and $\$ 1.1$ million $(0.23 \%)$ under the 400,000 af limit. Under the 400,000 af limit agriculture loses $\$ 1.2$ million, or $18.7 \%$ of base income level while municipal surplus is reduced by $\$ 4.3$ million (about 1\%). (Note that municipal surplus percent change is small because we are dealing with a constant elasticity demand curve.) Industrial surplus falls by $\$ 130,000$, or $4.6 \%$. Simultaneously, an additional $\$ 4.55$ million a year accrues to water agencies or water rights holders. Thus the pumpers lose $\$ 5.68$ million a year (areas b and c, above) whereas the agencies and rights holders gain $\$ 4.55$ million, leaving a net regional loss of $\$ 1.13$ million. As shown in the theoretical section above, for society to gain as a whole, this $\$ 1.13$ million must be recouped through the value of the additional activities stimulated by the increased spring flow. Thus, if total net benefit is the standard for making decisions, then at least $\$ 1.13$ million must be gained annually through the value of the continued existence of the endangered species, the increased aquifer elevation, and the benefits of increased spring flows, including the improved ecological characteristics in the rivers fed by spring flows, the increased recreational and other social values stimulated by expanded in-stream flows, and the value of additional downstream water consumption permitted by the increased spring flows.

The results show, under the 400,000 af $\left(490\right.$ million $\mathrm{m}^{3}$ ) limit, that average Comal spring flow almost triples, increasing by 184,000 af $\left(230\right.$ million $\left.\mathrm{m}^{3}\right)$ from the base level of 97,000 af
(120 million $\mathrm{m}^{3}$ ). Further, the smallest monthly Comal spring flow under the worst case recharge (approximately 50,000 af, or 68 million $\mathrm{m}^{3}$ ) has risen from zero to 250 cubic feet per second (cfs; $7 \mathrm{~m}^{3} \mathrm{~s}^{-1}$ ), which is above the U.S. Fish and Wildlife Service (USFWS) take and jeopardy levels, which are 200 and $150 \mathrm{cfs}$ ( 6 and $4 \mathrm{~m}^{3} \mathrm{~s}^{-1}$ ), respectively, as described in the next section [USFWS, 1995].

Irrigated acres are reduced under the 400,000 af (490 million $\mathrm{m}^{3}$ ) pumping limit by 27,000 acres $(11,000 \mathrm{ha}$; almost $33 \%$ ). Eastern agricultural water use falls by over $75 \%$ whereas western use falls by about $17 \%$ due to higher pump lifts. Municipal use is reduced by 1000 af $\left(1.2\right.$ million $\left.\mathrm{m}^{3}\right)$ in the west and 22,000 af $\left(27\right.$ million $\left.\mathrm{m}^{3}\right)$ in the east. Total average water use falls from 501,000 af $\left(62\right.$ million $\left.\mathrm{m}^{3}\right)$ down to the 400,000 af limit. The elevation of the San Antonio reference well rises by 44 feet $(14 \mathrm{~m})$ in the typical year.

The pumping limit causes agriculture relative to municipal and industrial uses to experience larger water and percentage welfare adjustments, particularly in the east. This occurs because (1) the regression shows that eastern usage has more profound implications for eastern pumping lifts, (2) a less profitable overall crop mix is used in the east (which is congruent with historic observation), and (3) agricultural use values are smaller than municipal and industrial use values on the margin. Annual welfare reductions to the pumping users are almost a million dollars less under the 450,000 af (560 million $\mathrm{m}^{3}$ ) limit than the 400,000 af (490 million $\mathrm{m}^{3}$ ) limit. Considerable revenues could accrue to those allocating the rights 
Table 3. Total Pumping Usage under Alternative Scenarios

\begin{tabular}{cccccc}
\hline $\begin{array}{c}\text { Typical } \\
\text { Weather } \\
\text { Year* }\end{array}$ & Probability & $\begin{array}{c}\text { Recharge, } \\
\text { Thousands of } \\
\text { Acre-Feet }\end{array}$ & $\begin{array}{c}\text { Base Usage, } \\
\text { Thousands of } \\
\text { Acre-Feet }\end{array}$ & $\begin{array}{c}\text { 450,000 Acre-Foot } \\
\text { Pumping Limit, } \\
\text { Thousands of } \\
\text { Acre-Feet }\end{array}$ & $\begin{array}{c}\text { Usage When Spring Flow } \\
\geq 200 \text { cfs, Thousands } \\
\text { of Acre-Feet }\end{array}$ \\
\hline 1956 & 0.018 & 43.7 & 537.8 & 450.0 & 401.8 \\
1951 & 0.018 & 140.1 & 535.1 & 450.0 & 433.6 \\
1963 & 0.089 & 170.8 & 526.9 & 450.0 & 442.4 \\
1989 & 0.143 & 214.5 & 521.0 & 450.0 & 46.0 \\
1980 & 0.214 & 406.3 & 519.6 & 450.0 & 445.5 \\
1974 & 0.214 & 658.4 & 497.8 & 450.0 & 412.2 \\
1976 & 0.214 & 894.1 & 463.9 & 445.8 & 434.9 \\
1958 & 0.071 & 1701.2 & 487.7 & 450.0 & 409.8 \\
1987 & 0.018 & 2003.6 & 454.3 & 439.8 & 438.3 \\
Average & $\ldots$ & 626.9 & 501.0 & 448.9 & \\
\hline
\end{tabular}

One acre-foot equals $1234 \mathrm{~m}^{3} ; 1$ cubic foot equals $0.028 \mathrm{~m}^{3}$.

*These weather years provide the states of nature used in the model.

under the pumping limit, which might need to be dissipated if a public utility were involved.

\subsection{Consideration of Spring Flow Limits}

The EAA is charged with maintaining spring flow. The USFWS has estimated that Comal flows less than $200 \mathrm{cfs}\left(6 \mathrm{~m}^{3}\right.$ $\mathrm{s}^{-1}$ ), the "take" level, will result in unsuitable habitat for the endangered fountain darter species, while finding that $150 \mathrm{cfs}$ $\left(4 \mathrm{~m}^{3} \mathrm{~s}^{-1}\right)$ is the Comal "jeopardy" level. In order to investigate the implications of maintaining spring flow we ran four minimum spring flow scenarios placing a lower bound on the monthly SPRNFLOW variable from (17). These scenarios require $50,100,150$, and $200 \mathrm{cfs}\left(1,3,4,6 \mathrm{~m}^{3} \mathrm{~s}^{-1}\right)$ of Comal flow during each and every month. Some of these levels are underneath the USFWS take and jeopardy levels. However, during August of 1996 spring flow fell to $79 \mathrm{cfs}\left(2 \mathrm{~m}^{3} \mathrm{~s}^{-1}\right)$ even though the USFWS levels had been announced.

The results show that relatively small adjustments can guarantee the lower spring flow minima. However, the $200 \mathrm{cfs}\left(6 \mathrm{~m}^{3}\right.$ $\mathrm{s}^{-1}$ ) minimum requires relatively larger adjustments. The welfare lost by pumping users to achieve this level of spring flow is only about half as much as that implied under the 400,000 af ( 490 million $\mathrm{m}^{3}$ ) limit because the use of water generating spring flows above those needed is not allowed even if available. In particular, a $200 \mathrm{cfs}$ limit reduces pumping user welfare by about a half million dollars a year. This rises through welfare losses of about $\$ 0.5$ million to agriculture, $\$ 3$ million to municipal interests, and $\$ 80,000$ to industrial interests, but a $\$ 3.2$ million increase in the welfare account accruing to water rights and agencies. In terms of irrigation, irrigated acreage falls by about $25 \%$. Again the most substantial adjustment is in eastern water use by agriculture and municipal interests again because of the Knippa gap as discussed above.

These adjustments are stimulated by a pumping pattern which adjusts to climate, as implied in Figure 2. Table 3 details water use under the $200 \mathrm{cfs}\left(6 \mathrm{~m}^{3} \mathrm{~s}^{-1}\right)$ and 450,000 af $(560$ million $\mathrm{m}^{3}$ ) scenarios. The $200 \mathrm{cfs}$ column shows that when recharge is low, usage approaches 400,000 af (490 million $\mathrm{m}^{3}$ ). However, as recharge grows, so initially does usage until at high levels demand is reduced by abundant rainfall. The reductions in usage relative to the base are greater the dryer the year. This result implies that pumping limit or water cost policies, which vary with aquifer water supply, would be desirable to take advantage of plentiful or scarce water.

\subsection{Agricultural Water Use Guarantees}

The above results arise from a scheme which allocates limited EA water so as to maximize total regional welfare. The EDSIM structure allocates water in a manner that implies that agriculture would forego pumping to allow higher-valued users access to water. In practice, that would be unlikely without compensation. Further, most of the agricultural use is west of the municipal use, and EA water flows from west to east. Thus agriculture generally has first access to the water.

Here we explore the implications of agriculture being guaranteed the amounts suggested in SB1477. Namely, agricultural water use will be no less than either (1) the base unrestricted level of usage adjusted down proportionally or (2) 2 af per acre $\left(2500 \mathrm{~m}^{3}\right.$ per $0.4 \mathrm{ha}$, or $6800 \mathrm{~m}^{3}$ per hectare) irrigated. These minima are imposed on all acres in all counties in all lift zones as a lower bound on the AGWATER variable. Also for now we do not allow agriculture to sell or lease water.

Table 4 presents the agricultural guarantee results under the 400,000 af ( 490 million $\mathrm{m}^{3}$ ) limit. The optimal column gives EDSIM results under the pumping limit when agricultural water use is not guaranteed. The next two columns give the results under the proportional and 2 af $\left(2500 \mathrm{~m}^{3}\right)$ guarantees. (The two market columns will be discussed in the next section.)

The results demonstrate water use and welfare trade-offs between sectors. Under guarantees, average agricultural welfare is $22-35 \%$ higher. These welfare gains occur due to $15-$ $50 \%$ higher agricultural water use associated with the guarantee particularly in the east. However, total welfare is reduced by $\$ 0.3$ million to $\$ 3$ million with the agricultural gains achieved at the expense of nonagricultural users. Equivalently, without an agricultural guarantee, the gains by nonagricultural users are achieved at agriculture's expense (in the absence of compensation for reduced water use).

The results show the choice of guarantees involves more than a million dollars annually at a 400,000 af (490 million $\left.\mathrm{m}^{3}\right)$ limit. There the 2 af $\left(2500 \mathrm{~m}^{3}\right)$ guarantee has a million dollar greater annual welfare effect.

\subsection{Water Markets}

The results under the agricultural pumping guarantees show there is room for the establishment of water markets. EDSIM, in effect, simulates water use under an idealized water market with no transactions cost. We examine the effects of not having a water market by imposing water usage minimums by parties 
Table 4. Welfare Effects of Agricultural Guarantees and Water Markets: 400,000 AcreFoot Pumping Limit

\begin{tabular}{|c|c|c|c|c|c|}
\hline & \multirow[b]{3}{*}{ Optimal } & \multicolumn{4}{|c|}{ Guarantee, Change From Optimal } \\
\hline & & \multirow[b]{2}{*}{ Proportion } & \multirow[b]{2}{*}{2 Acre-Feet } & \multicolumn{2}{|c|}{ With Market } \\
\hline & & & & Proportion & $\begin{array}{l}\text { Proportion/ } \\
1 \text { Acre-Foot }\end{array}$ \\
\hline \multicolumn{6}{|c|}{ Average Welfare Measures } \\
\hline Agriculture income, $10^{6} \$$ & 5.17 & 1.14 & 1.82 & 0.18 & 0.62 \\
\hline Percent change & ... & 22.04 & 35.13 & 3.46 & 12.05 \\
\hline Municipal surplus, $10^{6} \$$ & 466.84 & -9.89 & -16.57 & -1.18 & -5.03 \\
\hline Percent change & ... & -2.12 & -3.55 & -0.25 & -1.08 \\
\hline Industry surplus, $10^{6} \$$ & 2.64 & -0.26 & -0.43 & -0.03 & -0.13 \\
\hline Percent change & $\cdots$ & -9.83 & -16.41 & -1.07 & -5.09 \\
\hline Authority surplus, $10^{6} \$$ & 11.54 & 7.92 & 13.09 & 0.97 & 4.08 \\
\hline Percent change & $\cdots$ & 68.66 & 113.46 & 8.38 & 35.34 \\
\hline Total surplus, $10^{6} \$$ & 486.20 & -1.09 & -2.09 & -0.06 & -0.47 \\
\hline Percent change & $\cdots$ & -0.22 & -0.43 & -0.01 & -0.10 \\
\hline \multicolumn{6}{|c|}{ Agricultural Measures } \\
\hline Irrigation development, $10^{3}$ acres & 52.91 & 17.39 & 26.31 & 2.76 & 14.65 \\
\hline Dryland usage, $10^{3}$ acres & 26.98 & -17.39 & -26.31 & -2.76 & -14.65 \\
\hline \multicolumn{6}{|c|}{ Water Use } \\
\hline East agricultural, $10^{3}$ acre-feet & 18.44 & 42.79 & 55.59 & 6.20 & 28.55 \\
\hline West agricultural, $10^{3}$ acre-feet & 73.33 & -3.50 & 4.64 & -0.92 & -6.79 \\
\hline East nonagricultural, $10^{3}$ acre-feet & 299.51 & -38.04 & -58.31 & -5.13 & -21.08 \\
\hline West nonagricultural, $10^{3}$ acre-feet & 8.72 & -1.25 & -1.92 & -0.15 & -0.69 \\
\hline \multicolumn{6}{|c|}{ Hydrological Measures } \\
\hline Comal spring flow, $10^{3}$ acre-feet & 281.47 & -9.16 & -1.79 & -1.82 & -11.16 \\
\hline San Marcos spring flow, $10^{3}$ acre-feet & 83.72 & -0.97 & -0.06 & -0.20 & -1.26 \\
\hline J17 well ending elevation, feet & 685.84 & -1.38 & 0.79 & -0.31 & -2.17 \\
\hline Minimum Comal spring flow, cfs & 250.56 & -5.31 & 1.85 & -1.06 & -7.64 \\
\hline
\end{tabular}

Note the scenario definitions are as follows: "Proportion" means agriculture gets its proportional share; " 2 acre-feet" indicates no more than 2 acre-feet of water can be used per acre (as opposed to 2.12 in the base scenario); "with market" means that permanent sale of water is allowed; and "proportion/1 acre-foot" means that agricultural gets its proportional share but must retain use of at least 1 acre-foot per acre. One acre-foot equals $1234 \mathrm{~m}^{3} ; 1$ cubic foot equals $0.028 \mathrm{~m}^{3} ; 1$ foot equals $0.3048 \mathrm{~m}$.

who do not freely participate in water sales by placing lower bounds on the AGWATER variable. Then through comparison with the unrestricted model, we evaluate the economic implications of market presence.

Two market forms are considered: temporary (lease) and permanent (sale) markets. We examined potential trades between agricultural and non agricultural interests under the 400,000 af (490 million $\mathrm{m}^{3}$ ) limit. In particular, we develop our discussion from results of four water marketing related scenarios under the 400,000 af limit.

1. Agriculture does not trade any water and is guaranteed its proportional share (the second column in Table 4).

2. Agriculture is deeded its proportional share and can sell water to nonagricultural interests, but the same amount of water is required to be transferred across all states of nature simulating a permanent water sale of a given number of acrefeet (the next to last column in Table 4).

3. Agriculture realizes the guarantees of case 2 but must retain usage of 1 af per acre $\left(2500 \mathrm{~m}^{3}\right.$ per $0.4 \mathrm{ha}$, or $6800 \mathrm{~m}^{3}$ per hectare) following a restriction appearing in SB1477 (the last column in Table 4).

4. Agriculture sells whatever it wants with the volume sold varying by state of nature (the first column in Table 4).

Table 5 presents results on water marginal value product (MVP), derived as a weighted average of monthly and recharge-dependent shadow prices for water less the pumping cost under these scenarios. In the absence of a water transfer mechanism, there is about a $\$ 70$ per acre-foot $(\$ 170$ per hectare) difference in MVPs. Allowing permanent sales reduces the MVP disparity to about $\$ 4$ ( $\$ 41.64$ to $\$ 37.55$ ) per acre-foot ( $\$ 10$ per hectare) in the east or about $\$ 5$ (\$12 per hectare) in the west. When leasing is allowed, the MVPs are almost equal with slight differences due to seasonality in water use intensities. (Note that the MVPs are usage-weighted averages across

Table 5. Marginal Value of Water under Three Water Marketing Scenarios at the 400,000 Acre-Foot Limit

\begin{tabular}{lccc}
\hline & $\begin{array}{c}\text { Base 400-No } \\
\text { Guarantee } \\
\text { (Leasing) }\end{array}$ & No Market & $\begin{array}{c}\text { Permanent } \\
\text { Sale }\end{array}$ \\
\hline Agriculture water value & East & & \\
Nonagriculture water value & 38.23 & 26.15 & 37.55 \\
& 37.66 & 99.93 & 41.64 \\
Agriculture water value & West & & \\
Nonagriculture water value & 30.21 & 21.23 & 28.02 \\
\hline
\end{tabular}

Values given in dollars per acre-foot. One acre-foot equals $1234 \mathrm{~m}^{3}$. Note that the base 400-no guarantee scenario allows agriculture to vary water sold across state of nature while the permanent sale scenario depicts the same amount of water sold by agriculture in each and every state of nature. 
all states of nature and months. So in cases differences arise between agricultural and nonagricultural values due to the fact that these are a composite of 108 differentially weighted shadow prices across months and recharge years. The water value differs slightly owing to place and time of diversion.) The data in Table 4 for the water market scenarios show that most of the losses in the municipal and industrial areas can be mitigated by water markets. However, these results do not consider the magnitude of the transaction costs involved in the parties finding each other or factor in the agricultural and municipal welfare implications of water payments. Hence we conclude that the emergence of an active market is likely.

\section{Concluding Comments}

The economic impacts of Texas Senate Bill 1477 provisions which deal with management of the Edwards Aquifer were investigated using a multiuser, stochastic, linked economichydrologic simulation model. The results indicate that the near term consequences of a 450,000 af $\left(560\right.$ million $\left.\mathrm{m}^{3}\right)$ total pumping limit plan are not large (around $\$ 300,000$ per year). The simulations show that the 400,000 af $\left(490\right.$ million $\mathrm{m}^{3}$ ) limit will cause the springs to flow above the endangered species critical limits. However, as the limit is reduced to 400,000 af some users show almost a 75\% drop in water use, particularly eastern irrigators. This reduces total agricultural income by $18.7 \%$. Simultaneously, the plan decreases municipal and industrial sector welfare by about $\$ 4.6$ million $(1 \%)$, but generates a $\$ 4.5$ million return to water rights, agencies or permit holders. Overall, a 400,000 af pumping limit reduces pumping user welfare by $\$ 1.1$ million per year. Such losses would be offset through gains from increased spring flows at Comal and San Marcos Springs and higher ending aquifer elevation. For the spring flow limitation to the yield and economic gain for society the gains from these other sources would have to exceed the $\$ 1.1$ million annual loss borne by Edwards Aquifer pumping users.

The results also indicate that an active water market is likely to arise under the tighter pumping limits. For example, when historic levels of agricultural use are guaranteed, then the study results show water use value differences of more than $\$ 70$ per acre-foot ( $\$ 170$ per hectare). An active water market can reduce this difference thereby benefitting both sectors.

Finally, the results indicate that minimum spring flow can be achieved at a higher level of pumping than the 400,000 af (490 million $\mathrm{m}^{3}$ ) limit, but that total allowed water use needs to be sensitive to weather and recharge with less water consumed under the dryer events. This would require implementation of a more complex water use management regime such as the seniority system used for western water rights.

Acknowledgments. B. A. McCarl is Professor of Agricultural Economics, Texas A\&M University; C. R. Dillon is Associate Professor of Agricultural Economics, University of Kentucky; K. O. Keplinger is Research Economist, Tarlton State University; and R. L. Williams is Assistant Professor, California State University, Fresno. Thanks to Ron Griffin, Ron Lacewell, Manzoor Chowdhury, Perry New, Wayne Jordan, and two anonymous reviewers for contributions and comments. This research project was sponsored by the Texas Water Resources Institute and the Texas Agricultural Experiment Station. This manuscript was done in association with the USDA NRCS cooperative agreement and with Texas A\&M University entitled Natural Resource Modeling and Policy Analysis. B. A. McCarl is senior author. The other authors all contributed equally.

\section{References}

Baumol W. J., and W. E. Oates, The Theory of Environmental Policy: Externalities, Public Outlays, and the Quality of Life, Prentice-Hall, Englewood Cliffs, N. J., 1975.

Collinge, R., P. Emerson, R. C. Griffin, B. A. McCarl, and J. Merrifield, The Edwards Aquifer: An economic perspective, TR-159, Tex. Water Resour. Inst., Tex. A\&M Univ., College Station, 1993.

Dantzig, G. B., Linear programming under uncertainty, Manage. Sci., 1, 197-206, 1955.

Dillon, C. R., An economic analysis of Edwards Aquifer water management, Ph.D. dissertation, Tex. A\&M Univ., College Station, 1991.

Gharbi, A., and R. C. Peralta, Integrated embedding optimization applied to Salt Lake Valley aquifers, Water Resour. Res., 30, 817832, 1994.

Griffin, R. C., and C. Chang, Seasonality in community water demand, West. J. Agric. Econ., 16, 207-217, 1991.

Howe, C. W., D. R. Schurmeier, and W. D. Shaw Jr., Innovative approaches to water allocation: The potential for water markets, Water Resour. Res., 22, 439-445, 1986.

Keplinger, K. O., An investigation of dry year options for the Edwards Aquifer, Ph.D. dissertation, Tex. A\&M Univ., College Station, 1996.

Keplinger, K. O., and B. A. McCarl, Regression based investigation of pumping limits on springflow within the Edwards Aquifer, Dep. of Agric. Econ., Tex. A\&M Univ., College Station, 1995.

Keplinger, K., B. McCarl, M. Chowdhury, and R. Lacewell, Economic and hydrologic implications of suspending irrigation in dry years, $J$. Agric. Resour. Econ., 23, 191-205, 1998.

Lacewell, R. D., and B. A. McCarl, Estimated effect of USDA commodity programs on annual pumpage from the Edwards Aquifer, Final report submitted to Nat. Resour. Conserv. Serv., U.S. Dep. of Agric., Temple, Tex., 1995.

Longley, G., The subterranean aquatic ecosystem of the Balcones fault zone Edwards Aquifer in Texas-Threats from overpumping, paper presented at First International Conference on Ground Water Ecology, U.S. Environ. Prot. Agency, Tampa, Florida, April 26-29, 1992.

McCarl, B. A., Cropping activities in agricultural sector models: A methodological proposal, Am. J. Agric. Econ., 64, 768-772, 1982.

McCarl, B. A., and G. H. Parandvash, Irrigation development versus hydroelectric generation: Can interruptible irrigation play a role?, West. J. Agric. Econ., 13, 267-276, 1988.

McCarl, B. A., and T. H. Spreen, Price endogenous mathematical programming as a tool for sector analysis, Am. J. Agric. Econ., 62, 87-102, 1980.

McCarl, B. A., W. R. Jordan, R. L. Williams, L. L. Jones, and C. R. Dillon, Economic and hydrologic implications of proposed Edwards Aquifer management plans, TR-158, Tex. Water Resour. Inst., Tex. A\&M Univ., College Station, 1993.

Michelsen, A. R., and R. A. Young, Optioning agricultural water rights for urban water supplies during drought, Am. J. Agric. Econ., 75, 1010-1020, 1993.

Renzetti, S., An economic study of industrial water demands in British Columbia, Canada, Water Resour. Res., 24, 1569-1573, 1988.

Schaible, G. D., Summary/interpretation: Three county irrigation survey of irrigators in the EA area, in Biological Evaluation of USDA Farmer Assistance and Rural Development Programs Implemented in Bexar, Medina, and Uvalde Counties, Texas on EA Threatened and Endangered Aquatic Species, appendix II, Nat. Resour. Conserv. Serv., U.S. Dep. of Agric., Temple, Tex., 1996.

Texas Legislature, Senate Bill 1477, 73rd session, Austin, May 1993.

Thorkildsen, D., and P. D. McElhaney, Model refinement and applications for the Edwards (Balconies Fault Zone) Aquifer in the San Antonio region, Texas, Rep. 340, Tex. Water Dev. Board, Austin, 1992.

U.S. Fish and Wildlife Service, San Marcos/Comal recovery plan, Albequerque, N. M., 1995.

U.S. Geological Survey, Recharge to and discharge from the Edwards Aquifer in the San Antonio Area, Texas, Austin, Tex., 1997. (Available at http://tx.usgs.gov/reports/district/98/01/index.html.)

Vaux, H. J., and R. E. Howitt, Managing water scarcity: An evaluation of interregional transfers, Water Resour. Res., 20, 785-792, 1984.

Ward, F. A., and T. P. Lynch, Is dominant use management compatible with basin-wide economic efficiency?, Water Resour. Res., 33, 1165$1170,1997$.

Water Strategist, On groundwater control and markets: Managing the Edwards Aquifer, newslet., vol. 10, no. 3, 1996. 
Williams, R. L., Drought management and the Edwards Aquifer: An economic inquiry, Ph.D. dissertation, Tex. A\&M Univ., College Station, 1996

Williams, J. R., C. A. Jones, J. R. Kiniry, and D. A. Spaniel, The EPIC crop growth model, Trans. ASAE, 32, 497-511, 1989.

Ziari, H. A., B. A. McCarl, and C. A. Stockle, Nonlinear mixed integer program model for evaluating runoff impoundments for supplemental irrigation, Water Resour. Res., 31, 1585-1594, 1995.

C. R. Dillon, Department of Agricultural Economics, University of Kentucky, Ag Engineering Bldg., Lexington, KY 40506-0276.
K. O. Keplinger, TIAER, Tarleton State University, Box 10410, Tarelton Station, Stephenville, TX 76402.

B. A. McCarl, Department of Agricultural Economics, Texas A\&M University, College Station, TX 77843-2124. (mccarl@ranger. tamu.edu

R. L. Williams, California State University, 5245 N. Backer Avenue, M/SPB 101, Fresno, CA 93740-8001.

(Received June 1, 1998; revised November 30, 1998; accepted December 11, 1998.) 